\title{
Patient-specific anti-acetylcholine receptor antibody patterns in myasthenia gravis
}

\author{
THÉRĖSE SAVAGE-MARENGO, ROGER HARRISON, GEORGE G LUNT, AND \\ PETER O BEHAN
}

From the Department of Biochemistry, University of Bath and the Department of Neurology, Institute of Neurological Sciences, Glasgow

SUMMARY Anti-acetylcholine receptor (AChR) antibodies have been determined in the sera of ten myasthenic patients over a period of several months which in each case included a series of plasma-exchanges coupled with immunosuppressive therapy. The ratio of anti-(extra-junctional rat $\mathrm{AChR}$ ): anti-(human $\mathrm{AChR}$ ) antibody titres was found to vary with the patient but to be constant for a given patient over the period of study. Similar indications of a patient-specific antiAChR antibody pattern were obtained by using junctional as well as extra-junctional rat AChR and also by precipitation of human $\mathrm{AChR}$ in the presence of excess antiserm. Individual anti-AChR antibody patterns may have relevance to the varying courses taken by myasthenia gravis in different patients.

Myasthenia gravis is an autoimmune disease in which the acetylcholine receptor (AChR) at the neuromuscular junction is a major auto-antigen. ${ }^{1}$ Anti-AChR antibodies are usually present in the sera of myasthenic patients ${ }^{2}$ and this provides an aid to diagnosis of the disease although the correlation of anti-(human AChR) antibody titres with disease state is generally poor. ${ }^{3-5}$ We recently examined ${ }^{6}$ the relative merits of human and rat AChR as antigen in the routine radioimmunoassay of anti-AChR antibodies in the sera of patients with myasthenia gravis. The anti(rat AChR) antibody titres were generally found to be much lower than corresponding anti(human AChR) titres and, like the latter, showed no obvious correlation with severity of symptoms in the myasthenic patients. Although the ratio of anti-(rat AChR) antibody titre: anti-(human AChR) antibody titre varied widely from patient to patient, limited numbers of serial serum assays on individual patients suggested that the ratio might be constant for and characteristic of a given patient. In view of the possible implications of these observations for the mechanisms of pathogenesis of myasthenia gravis, we have examined both anti-(rat AChR) and anti-(human AChR) antibody titres in the sera of ten myas-

Address for reprint requests: Dr R Harrison, Biochemistry Department University of Bath, Claverton Down, Bath BA2 7AY.

Accepted 7 February 1980 thenic patients monitored over a span of several months which included periods of plasmaexchange combined with immunosuppressive therapy.

\section{Patients and methods}

Ten patients with myasthenia gravis were studied. There were 6 females and 4 males, whose ages ranged from 26 to 75 years with a mean of 49 years. Nine patients had the generalized form of the disease whereas in one (Case 6) the eye muscles only were clinically affected. Myasthenia had been present from three to 18 years with a mean duration of seven years. Nine patients had had a thymectomy previously.

During the period of study all patients underwent at least one course of plasma exchanges. Each course ranged from one to eight individual exchanges of four litres of plasma. Replacement fluid was plasma protein fraction.

All patients were on anticholinesterase therapy throughout the period of study and were placed on prednisolone (100 $\mathrm{mg}$ daily) and azathioprine $(150 \mathrm{mg}$ daily) at the commencement of plasma exchange. The azathioprine dose was maintained for three months but the steroids were gradually reduced over this period.

${ }^{125}$ I-IODINATION OF $\alpha$-BUNGAROTOXIN

$\alpha$-Bungarotoxin from Bungarus multicinctus was 
purchased from Boehringer, Mannheim, Germany and radio-iodinated as previously described. 5

PREPARATION OF SOLUBLE AChR

Human skeletal muscle AChR Human skeletal muscle was obtained from amputated legs at the time of operation and either used immediately or stored at $-20^{\circ} \mathrm{C}$. The chopped muscle was homogenised $(1 \mathrm{~min})$ at $+4^{\circ} \mathrm{C}$ in four volumes

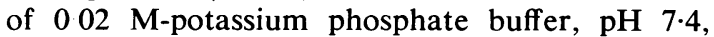
containing $1 \mathrm{mM}$ EDTA, $0.5 \mathrm{mM}$-phenylmethylsulphonyl fluoride (Sigma London Chemical Co, Poole, UK), $0 \cdot 1$ mM-benzethonium chloride (Sigma London Chemical Co) and $0.02 \% \mathrm{NaN}_{3}$ and centrifuged at $20000 \mathrm{~g}$ for $45 \mathrm{~min}$ at $+4^{\circ} \mathrm{C}$. The pellet was resuspended and homogenised in 1 volume of the above buffer with the addition of $2.5 \% \%$ Triton X-100, stirred for $15 \mathrm{~h}$ at $+4^{\circ} \mathrm{C}$ and centrifuged at $20000 \mathrm{~g}$ for $5 \mathrm{~min}$ and then at $100000 \mathrm{~g}$ for $45 \mathrm{~min}$. The resulting supernatant was filtered through glass wool to remove lipid particles and stored at $+4^{\circ} \mathrm{C}$.

Extra-junctional (e.j.) rat $A C h R$ Diaphragms from three months old female Wister rats were unilaterally denervated under diethyl ether anaesthesia by section of the left phrenic nerve within the pleural cavity. After 18 days the rats were killed by cervical dislocation and their diaphragms were removed. The denervated hemidiaphragms were finely chopped with a razor blade and stirred in three volumes of phosphatebuffered Triton $\mathrm{X}-100$ for $15 \mathrm{~h}$ at $+4^{\circ} \mathrm{C}$ as described above for human skeletal muscle. The extract was centrifuged at $100000 \mathrm{~g}$ for $30 \mathrm{~min}$ and the supernatant was used as a source of e.j. rat AChR.

Junctional (j) rat AChR The end-plate regions from innervated rat diaphragms were dissected out and treated as described above for denervated diaphragms. The resulting supernatant was used as a source of $\mathrm{j}$. rat $\mathrm{AChR}$.

DETERMINATION OF AChR CONCENTRATION

The concentration of AChR in receptor preparations was determined by the specific binding of ${ }^{125} \mathrm{I}-\alpha$-bungarotoxin. The receptor extract $(100$ $\mu 1)$ was incubated with $20 \mathrm{nM}^{125} \mathrm{I}$ - $\alpha$-bungarotoxin solution $(50 \mu 1)$ for $90 \mathrm{~min}$ at $+20^{\circ} \mathrm{C}$. Saturated aqueous $\left(\mathrm{NH}_{4}\right)_{2} \mathrm{SO}_{4}$ solution was added to $40 \%$ overall saturation and the mixture was stored for $20 \mathrm{~h}$ at $+4^{\circ} \mathrm{C}$. The resulting precipitate was collected on glass fibre filters (Whatman Biochemicals, Maidstone, UK). washed with $40 \%$ aqueous $\left(\mathrm{NH}_{4}\right)_{2} \mathrm{SO}_{4}$ solution and counted in a $\gamma$-counter. A parallel assay was carried out as above except that the incubation mixture additionally contained 2.5 mM-benzoquinonium chloride (generously given by SterlingWinthrop Research Institute, Rensselaer, New York, USA) and the counts so obtained were subtracted to give specific binding.

ASSAY OF ANTI-AChR ANTIBODIES

Anti-(human AChR) antibodies and anti-(rat AChR) antibodies in the sera of myasthenic patients were assayed by using ${ }^{125} \mathrm{I}$ - $\alpha$-bungarotoxin-labelled AChR in a modification of the assay described by Lindstrom. ${ }^{7}$

AChR extract containing approximately 0.5 $\mathrm{nM}$ specific toxin-binding sites was incubated for $90 \mathrm{~min}$ at $+20^{\circ} \mathrm{C}$ with a fivefold excess of ${ }^{125} \mathrm{I}$ - $\alpha$-bungarotoxin in phosphate-buffered Triton $\mathrm{X}-100$ (as above). The resulting ${ }^{125} \mathrm{I}-\alpha$-bungarotoxin-AChR solution $(100 \mu 1)$ was incubated with myasthenic serum or a sample $(5 \mu 1)$, seriallydiluted (with normal human serum), for $16 \mathrm{~h}$ at $+4^{\circ} \mathrm{C}$. The labelled $\mathrm{AChR}$-antibody complex was precipitated by addition of goat anti-(human IgG) antiserum and allowed to stand for $15 \mathrm{~h}$ at $+4^{\circ} \mathrm{C}$. The precipitate was separated by centrifugation at $3000 \mathrm{~g}$ for $10 \mathrm{~min}$ and the pellet was washed twice with $0.01 \mathrm{M}$-potassium phosphate buffer, pH $7 \cdot 4$, containing $0 \cdot 15 \mathrm{M}-\mathrm{NaC} 1,1 \% \mathrm{v} / \mathrm{v}$ Triton $\mathrm{X}-100,1 \% \mathrm{w} / \mathrm{v}$ bovine serum albumin and $0.02 \%$ $\mathrm{NaN}_{3}$ and counted in a $\gamma$-counter. Non-specific counts were subtracted as described above.

All assays were performed in duplicate and maximal precipitation of anti-(AChR) antibodies was ensured by the use of serially-diluted serum sample controls.

QUANTITATIVE PRECIPITATION OF HUMAN

AChR BY MYASTHENIC SERA

Human AChR extract containing approximately $0.25 \mathrm{nM}$ specific toxin-binding sites was labelled with excess of ${ }^{125} I-\alpha$-bungarotoxin as described for the assay of anti-AChR antibodies. Samples of the resulting labelled solution $(100 \mu 1$ and 25 $\mu 1)$ were incubated with myasthenic serum $(5 \mu 1)$ at $+4^{\circ} \mathrm{C}$ and the labelled AChR-antibody complex was precipitated by addition of goat anti(human IgG) antiserum as in the assay of antibodies. Conditions of antibody excess were ensured by adjusting the concentration of AChR used so that the amount of labelled AChR precipitated was proportional to the volume of AChR solution assayed. The relative abilities of myasthenic sera to precipitate AChR were checked using up to five different preparations of human AChR for a single myasthenic sample and the variation of percentage precipitation obtained 
was found to lie within that obtained using different samples from the same patient.

\section{Results and discussion}

Anti-AChR antibody titres were measured in the sera of ten myasthenic patients all of whom underwent a course of plasma-exchange coupled with immunosuppression during the period of in- vestigation. ${ }^{8}$ It has been reported elsewhere ${ }^{5}$ that anti-(human AChR) antibody titres fall dramatically during the course of such treatment and subsequently remain relatively low while the patient usually shows a marked and sustained clinical improvement. The patients chosen accordingly presented the opportunity to monitor relative variations in anti-(rat $\mathrm{AChR}$ ) and anti(human AChR) antibody titres during periods in

Table Anti-(rat AChR) and anti-(human AChR) antibody titres of myasthenic sera and differential precipitation of human AChR by excess of the sera

\begin{tabular}{|c|c|c|c|c|c|c|c|c|c|c|}
\hline \multirow[t]{2}{*}{ Case } & \multirow[t]{2}{*}{$\begin{array}{l}\text { Sex } \\
\text { Age }\end{array}$} & \multirow{2}{*}{$\begin{array}{l}\text { Duration } \\
\text { of } \\
\text { disease } \\
(v)\end{array}$} & \multirow{2}{*}{$\begin{array}{l}\text { Date } \\
\text { of } \\
\text { sample }\end{array}$} & \multicolumn{4}{|c|}{$\begin{array}{c}\text { Antibody titres } \times 10^{10} \\
(M)\end{array}$} & \multicolumn{2}{|l|}{ Ratios } & \multirow{2}{*}{$\begin{array}{l}\text { Human AChR } \\
\text { precipitated } \\
(\% \text { of Case } 3)\end{array}$} \\
\hline & & & & & $H$ & $E$ & & $\frac{E J R}{H}$ & $\frac{J R}{E J R}$ & \\
\hline 1 & F, 46 & 16 & \begin{tabular}{r|}
3.2 .78 \\
16.8 .78 \\
18.8 .78 \\
22.8 .78 \\
\end{tabular} & $\begin{array}{l}932 \\
764^{*} \\
630^{*} \\
616^{*}\end{array}$ & $\begin{array}{l}314 t \\
222+ \\
274+\end{array}$ & $\begin{array}{l}8 \\
6^{*} \\
0^{*} \\
0^{*}\end{array}$ & $\begin{array}{c}2+ \\
0 \dagger \\
10+\end{array}$ & $\begin{array}{c}0.010 \\
\pm 0.005(7)\end{array}$ & $0.00(2)$ & $\begin{aligned} & 75.00 \\
\pm & 3.18(7)\end{aligned}$ \\
\hline 2 & F, 26 & 4 & $\begin{array}{r}13.12 .77 \\
21.3 .78 \\
23.3 .78 \\
20.6 .78 \\
20.7 .78 \\
\end{array}$ & $\begin{array}{l}2784 \\
2244 \\
1188\end{array}$ & $\begin{array}{l}2163 \dagger \\
1620+\end{array}$ & $\begin{array}{l}72 \\
64 \\
24 \\
\end{array}$ & $\begin{array}{l}88+ \\
82+\end{array}$ & $\begin{aligned} & 0.034 \\
\pm & 0.005(5)\end{aligned}$ & 0.00 & $\begin{aligned} & 86 \cdot 20 \\
\pm & 0.73(5)\end{aligned}$ \\
\hline 3 & F, 31 & 7 & \begin{tabular}{r|}
27.8 .78 \\
29.8 .78 \\
4.9 .78 \\
5.9 .78
\end{tabular} & $\begin{array}{l}3018 \\
4432 \\
4508 * \\
3452\end{array}$ & $1438 \dagger$ & $\begin{array}{c}74 \\
110 \\
278^{*} \\
65\end{array}$ & $94 \dagger$ & $\begin{array}{c}0.043 \\
\pm 0.008(5)\end{array}$ & $\begin{array}{l}0.42 \\
\pm 0.009 \text { (3) }\end{array}$ & $103(5)$ \\
\hline 5 & M, 60 & 18 & $\begin{array}{r}19.4 .78 \\
8.6 .73 \\
9.6 .73 \\
19.6 .78 \\
21.6 .78\end{array}$ & $\begin{array}{c}533 \\
316^{*} \\
124^{*} \\
9 J^{*}\end{array}$ & $\begin{array}{l}30+ \\
20 \dagger \\
15 t \\
10 \dagger\end{array}$ & $\begin{array}{r}44 \\
26^{*} \\
6^{*} \\
6^{*}\end{array}$ & $\begin{array}{r}-2 \dagger \\
0.4 \dagger \\
1 \dagger \\
0 \dagger\end{array}$ & $\begin{array}{c}0.050 \\
+0.037(3)\end{array}$ & $\begin{array}{l}0.30 \\
\pm 0.05(3)\end{array}$ & $\begin{array}{l}85 \cdot 25 \\
+2.05(4)\end{array}$ \\
\hline$\overline{6}$ & F, 66 & 4 & \begin{tabular}{r|}
5.5 .78 \\
10.5 .78 \\
17.5 .78 \\
23.5 .78
\end{tabular} & $\begin{array}{l}4)^{*} \\
72^{*} \\
34^{*} \\
52^{*}\end{array}$ & $\begin{array}{l}10 t \\
12+ \\
14 t\end{array}$ & $\begin{array}{l}6^{*} \\
8^{*} \\
3^{*} \\
4^{*}\end{array}$ & $\begin{array}{l}1 \cdot 2 \dagger \\
1 \cdot 2 \dagger \\
1 \cdot 6 \dagger\end{array}$ & $\begin{array}{l}0.103 \\
\pm 0.007(7)\end{array}$ & $0.00(3)$ & $\begin{aligned} & 72 \cdot 33 \\
\pm & 3 \cdot 18(3)\end{aligned}$ \\
\hline 7 & F, 28 & 3 & $\begin{array}{r}2.10 .78 \\
4.10 .78 \\
9.10 .78 \\
13.10 .78\end{array}$ & $\begin{array}{l}1084^{*} \\
468^{*} \\
408^{*} \\
188^{*}\end{array}$ & $\begin{array}{r}288+ \\
106+ \\
98+ \\
26+\end{array}$ & $\begin{array}{r}150^{*} \\
60^{*} \\
40^{*} \\
22^{*}\end{array}$ & $\begin{array}{r}18+ \\
10 \dagger \\
8 \dagger \\
3+\end{array}$ & $\begin{array}{l}0.109 \\
\pm 0.007(8)\end{array}$ & $\begin{array}{l}0.87 \\
\pm 0.04(3)\end{array}$ & $\begin{aligned} & 53 \cdot 29 \\
\pm & 1.55(7)\end{aligned}$ \\
\hline 9 & F, 75 & 5 & $\begin{array}{r}1.2 .78 \\
7.2 .78 \\
14.2 .78 \\
13.3 .78 \\
21.3 .78 \\
10.4 .78 \\
4.8 .78 \\
29.8 .78\end{array}$ & $\begin{array}{r}106^{*} \\
66^{*} \\
42 \\
38 \\
250 \\
224\end{array}$ & $\begin{array}{l}32 \dagger \\
22 \dagger \\
24+ \\
48+\end{array}$ & $\begin{array}{l}24^{*} \\
10^{*} \\
12 \\
10 \\
40 \\
88\end{array}$ & $\begin{array}{r}10 \dagger \\
6+ \\
4+ \\
12+\end{array}$ & $\begin{array}{l}0.249 \\
\pm 0.024(10)\end{array}$ & $\begin{array}{l}0.16 \\
\pm 0.03(3)\end{array}$ & $\begin{aligned} & 66 \cdot 71 \\
\pm & 2.25(7)\end{aligned}$ \\
\hline$\overline{10}$ & M. 62 & 5 & $\begin{array}{r}30.11 .77 \\
7.12 .77 \\
3.5 .78 \\
4.5 .78 \\
5.5 .78 \\
11.5 .78\end{array}$ & $\begin{array}{r}82^{*} \\
80^{*} \\
194^{*} \\
110^{*} \\
124^{*} \\
120^{*}\end{array}$ & $\begin{array}{l}76 \\
84 \dagger \\
36 \dagger \\
32 \dagger \\
44 \dagger\end{array}$ & $\begin{array}{l}24^{*} \\
28^{*} \\
50^{*} \\
34^{*} \\
42^{*} \\
28^{*}\end{array}$ & $\begin{array}{l}28 \dagger \\
22 \dagger \\
14 \dagger \\
10 \dagger \\
12 \dagger\end{array}$ & $\begin{array}{l}0.313 \\
\pm 0.015(11)\end{array}$ & $\begin{array}{ll} & 0.50 \\
\pm & 0.14(3)\end{array}$ & $\begin{array}{l}48.00 \\
\pm 0.63(5)\end{array}$ \\
\hline
\end{tabular}

*-Pre plasma-exchange sera; †-post plasma-exchange sera; H-Anti (human AChR) antibody titre; JR-Anti (junctional rat AChR) antibody titre; EJR-Anti (extra junctional rat $A C h R)$ antibody titre; Data given as mean $\pm S . E . M$. (no. of serum samples). 
which the latter were known to vary widely and in which the patients underwent major changes in clinical state.

The table shows considerable patient-to-patient variation in anti-(human AChR) antibody titres and also the expected decrease in titre of an individual patient in association with each course of plasma-exchanges. Anti-(e.j. rat AChR) antibody titres were in all cases considerably lower than the corresponding anti-(human AChR) titre, ranging from 0 to $31 \%$ of the latter value. Like the latter, the anti-(e.j. rat AChR) antibody titres varied widely both between patients and during the course of treatment in a single patient. Despite such variations, however, the ratio of anti(e.j. rat AChR): anti-(human AChR) antibody titre remained remarkedly constant for an individual patient throughout the period of study. The fact that different anti-(AChR) antibody titres are obtained for a given sample of myasthenic serum assayed in the presence of excess of different receptor preparations clearly reflects the presence of discrete sub-populations of antiAChR antibodies in myasthenic serum. Heterogeneity of antibodies has been previously demonstrated by the use of combinations of different assay methods ${ }^{9-12}$ but studies of the extent to which patterns of antibody diversity are constant and characteristic of an individual myasthenic patient have not previously been reported. The constancy of the anti-(e.j. rat AChR): anti(human AChR) antibody ratio in the serum of any single myasthenic patient suggests that the deailed nature of the auto-immune response to AChR is characteristic of the individual patient and could perhaps be most simply explained in terms of a single initiating event.

It is of interest that the constant ratio of anti(e.j. rat AChR): anti-(human AChR) antibody titres is apparently unaffected by the combined plasma-exchange and immunosuppressive treatments experienced by all the patients monitored, despite the obvious fall in both titres during the period of treatment and the clear clinical improvement following the treatment. ${ }^{8}$ Moreover, titre ratios characteristic of the patient were also obtained from serum samples taken at intervals of up to several months before (Cases 1, 2, 3, 5) and after (Cases 2, 4, 9) plasma-exchange.

It has been suggested ${ }^{13}$ that plasma-exchange combined with anti-metabolite administration could lead to a semi-selective cytotoxic action in lymphocytes proliferating in response to removal of anti-AChR antibodies from the circulation, and the particular clinical effectiveness of an extensive series of plasma-exchanges coupled with azathioprine therapy would support this mechanism. ${ }^{5}$ It has been further suggested, following studies on experimental myasthenia gravis in rabbits, ${ }^{14}$ that azathioprine can selectively suppress certain anti-AChR antibody subpopulations. Our present results, while containing only a limited number of serum samples taken prior to azathioprine treatment, show no evidence of such selective suppression.

We also determined the anti-(j. rat AChR) antibody titre in selected serum samples from all ten myasthenic patients and the ratios of anti(j. rat AChR) : anti-(e.j. rat AChR) antibody titre are shown in the Table. The anti- $(j$. rat AChR) antibody titres were lower than the corresponding anti-(e.j. rat AChR) titres in all but two out of 28 serum samples assayed and could not be detected at all in samples taken from three patients (Cases 1, 2, 6). Weinberg and Hall ${ }^{12}$ similarly compared antiAChR antibody titres in 10 samples of myasthenic sera using junctional and extrajunctional rat $A C h R$ and found ratios of anti-(j. rat $A C h R)$ : anti-(e.j. rat $\mathrm{AChR}$ ) antibody titres varying from 0.6 to 1.0 . Our results clearly show a greater spread of ratios than those reported by Weinberg and Hall but agree with those of the latter authors in being generally less than 1.0 (table). Weinberg and Hall suggest that myasthenic serum, with its apparent content of anti-AChR antibodies specific for extrajunctional receptors. might find a use in detection and purification of such receptors. Our observation that some myasthenic sera (Cases 1, 2, 6) contain anti-(rat AChR) receptors only of this type strengthens the feasibility of this approach.

Although the ratios of anti-(j. rat $\mathrm{AChR})$ : anti-(e.j. rat $A C h R)$ antibody titres are not quite as consistent as the anti-(rat AChR): anti(human AChR) titre ratios previously discussed they do appear to be largely characteristic of the individual patient and so provide further support for the concept of a heterogeneous pattern of anti-AChR antibodies in myasthenic sera that is patient-specific.

The relative abilities of different myasthenic sera to precipitate $\alpha$-bungarotoxin-labelled human AChR were assessed. The amount of AChR precipitated from a given antigen solution by excess serum was found to vary with the serum sample. Samples from Case 3 consistently precipitated more AChR than did other sera which were accordingly routinely compared with the former sera (table). As can be seen from the table the amount of AChR precipitated by different serum samples from a given patient was 
approximately constant and varied between patients from 48 to $86 \%$ of the highest samples (all from Case 3). These results can be explained in terms of the absence of certain sub-populations of anti-AChR antibodies from all serum (itself an arbitrary figure) precipitation of AChR samples of those patients in which less than $100 \%$ is seen. While experiments of this type using excess of antiserum cannot report on relative proportions of anti-AChR antibodies present in a given serum sample, the consistency of the percentage precipitation of AChR shown by each patient provides further support for a patientspecific anti-AChR antibody pattern.

Differential precipitation of AChR by excess of antiserum not only implies heterogeneity of myasthenic anti-AChR antibodies but also of receptor itself or more strictly of $\alpha$-bungarotoxinbinding protein in the muscle homogenate. Our results and those of Weinberg and Hall ${ }^{12}$ have indeed shown immunological differences between junctional and extra-junctional AChR from rats while Vincent and Newsom-Davis ${ }^{11}$ have similarly reported different anti-AChR antibody titres for a given serum sample obtained by using normal calf and ocular human muscle as sources of AChR. In contrast to the above results, our data concerning differential precipitation of AChR in the presence of excess of antiserum imply the presence in Triton-soluble extracts of human muscle of some AChR molecules that show no cross-reactivity with other similarlylabelled AChR types and this finding is being further investigated.

The apparent constancy of anti-AChR antibody patterns of a given patient over a period of time and throughout a range of treatments may well have relevance to the progress of myasthenia gravis in any individual. The course of the disease in different patients and the responses of the latter to therapy are known to vary considerably and it may be that clues to the basis of these differences will be found in continued study of the patterns of anti-AChR antibody sub-populations and in their correlation with the case histories of myasthenic patients.

We thank the Muscular Dystrophy Group of Great Britain for financial support.

\section{References}

1 Simpson JA. Myasthenia Gravis: A personal view of pathogenesis and mechanism Part 2.
Muscle and Nerve 1978; 1:151-6.

2 Lindstrom JM, Seybold ME, Lennon VA, Whittingham S, Duane DD. Antibody to acetylcholine receptor in myasthenia gravis. Neurology 1976; 26:1054-9.

3 Lef vert AK, Bergstrom K, Matell G, Osterman PO, Pirskanen R. Determination of acetylcholine receptor antibody in myasthenia gravis: clinical usefulness and pathogenic implications. J Neurol Neurosurg Psychiatry 1978; 41:394-403.

4 Barkas T, Harrison R, Lunt GG, Stephenson FA, Behan PO, Simpson JA. Acetylcholine receptor antibody titres in myasthenia gravis. In: Behan PO, Clifford Rose A, eds. Progress in Neurological Research. Tunbridge Wells: Pitman Medical Press, 1979: 169-74.

5 Carter B, Harrison R, Lunt GG, Behan PO, Simpson JA. Anti-acetylcholine receptor antibody titres in the sera of myasthenic patients treated with plasma exchange combined with immunosuppressive therapy. J Neurol Neurosurg Psychiatry, submitted for publication.

6 Savage-Marengo T, Harrison R, Lunt GG, Behan PO. Rat or human acetylcholine receptor antigen for investigation of myasthenia gravis? Lancet 1979; 1:442.

7 Lindstrom J. An assay for antibodies to human acetylcholine receptor in serum from patients with myasthenia gravis. Clin Immunol Immunopath 1977; 7:36-43.

8 Behan PO, Shakir RA, Simpson JA, Burnett AK. Haase G, Allan TL. Plasma exchange combined with immunosuppressive therapy in the treatment of myasthenia gravis. Lancet 1979; ii:438-44.

9 Mittag TW, Tormay A, Marsa T. Heterogeneity of acetylcholine receptors in denervated muscle: interactions of receptors with immunoglobulin from patients with myasthenia gravis. Molec Pharmacol 1978; 14:60-8.

10 Dau PC. Yano MS, Ettinger SJ. Antibody to acetvlcholine receptor in canine and human mvasthenia gravis: Differential cross reactivity with human and rabbit receptor. Neurology 1979; 29:1065-8.

11 Vincent A. Newsom-Davis J. Bungarotoxin and anti-acetylcholine receptor antibody binding to the human acetvlcholine receptor. Adv in Cytopharmacol 1979: 3:269-78.

12 Weinberg CB. Hall ZW. Antibodies from patients with myasthenia gravis recognise determinants unique to extraiunctional acetvlcholine receptors. Proc Nat Acad Sci USA 1979: 76:504-8.

13 Dau PC. Lindstrom JM. Cassel CK. Denvs EH. Shev EE, Spitler LE. Plasmapheresis and immunosuppressive drug theranv in mvasthenia gravis. New Engl J Med 1977: 297:1134-40.

14 Furhs S. Immunology of the Nicotinic Acetylcholine Receptor. Current Tonics in Microbiologv and Immunology 1979; 85:1-30. 